ohtédnutí 



\section{Milanu Suchomelovi místo laudatia}

Tomáš Sedláček

Naposled jsem se s panem profesorem setkal loni. Vypadal, jak jsem si ho už takových patnáct let pamatoval, jen vlasy mu už zcela zestř́ibrněly. Jinak se nezměnil: sokolsky vzpřímená štíhle atletická postava muže s brýlemi, vysokým čelem a neodmyslitelně ironickým úsměvem. Řekl jsem mu to. „To je vás nedůstojné,“ odpověděl s nenapodobitelnou suchomelovskou ironií, čímž mi dal za pravdu.

Obávám se, že i následující řádky budou nedůstojny akademického světa, zato upřímné. Poprvé jsem se s Milanem Suchomelem setkal co studentík 3. ročníku bohemistiky, pravděpodobně v roce 1970-71. Byl tenkrát asistentem katedry české a slovenské literatury a literární vědy a přednášel nám moderní českou literaturu, k čemuž patřil také seminář. Moderní česká literatura začínala v Suchomelově přednášce tuším nástupem realismu a posléze České moderny; kdybych se nestěhoval, mohl bych říci, že své zápisky z těch přednášek mám ještě schované, protože tohle setkání bylo oslňující a ledasco zpo̊sobilo: Suchomel vsazoval literární vývoj do širokého proudu estetických, sociálních, světových i lokálních proudů i individuálních osudů. Jeho výklady dějin literatury se měnily ve vzrušující drama vývojového zápasu umění, tak si je aspoň uchovávám ve vzpomínce. Byla to vlastně velmi koncepčně promyšlená „filozofie (české) literatury“, jak se mi dnes zdá. (Přitom přednášky byly i plné pozoruhodných detailů a „špeků“ - jinak by se mne mohl při zkoušce stěží ptát, kdo to byl Smil z Rolničky - a já bych si to stěží mohl dodnes pamatovat...) Ale Milan Suchomel pochopitelně ovládal i dramatické kumšty a neváhal je použít. Vylíčiv v pochmurných barvách nihilistickou deziluzi nastupující generace anarchistů, ukončil naléhavě: „Co vlastně zbývá?“ A odpověděl citátem z Gellnerových $R a$ dostí života: „Alkohol ještě je, holky jsou dosud. / Jsou ještě radosti života." Pohlédl na hodinky a dodal: „To si povíme až přiště..." Virtuozita, za niž jsem ho opravdu nedůstojně obdivoval. 
Jiný svět byly Suchomelovy semináře, v nichž jsme se naopak věnovali soudobé, až nejčerstvější domácí literární produkci. Probrav s námi inspirativní metodu francouzské explikace textu, záhy na nás uhodil Bohem z reklamy Aleny Vostré. Nad první stránkou toho příběhu malého prvňáčka jsme strávili velmi bohatých devadesát minut. Zpočátku byly dosti krutou zkušeností, Milan Suchomel měl svéráznou a dobře propracovanou metodu, jak donutit shromážděné studentíky ke spolupráci: Zeptat se a počkat, až se ticho stane monumentálním a trapnost dostoupí takové výše, že někdo nevydrží a ticho prolomí. Subvarianta této edukativní metody byla osobnější: „Ted’ si poslechneme, jak mlčí pan XY či slečna YZ." Tohle mu u postižených popularity nepřidalo, ale nakonec dosáhl svého - názorů se začali dopouštět všichni a semináře se proměnily v prostor, kde se zkoumaná díla stala obětí široce aplikovaných znalostí i neznalostí, nápadů ad hoc, ale i argumentačně promyšlených reflexí, až k prvním hodnotícím soudům, leckdy v zápalu boje i značně kategorickým. Patřily k tomu i odbočky do základů estetických teorií a jejich praktických důsledků - a hlavně vědomí literárního i společenského kontextu díla. Už si přesně nevzpomenu, kdy jsem pro sebe objevil základy toho, co jsme s dr. Suchomelem probírali na semináŕích - totiž některé kapitoly z jeho chystané knihy Literatura z časů krize v Hostu do domu. Byly fascinující, byt jsem s některými závěry bouřlivě, tedy emocionálně nesouhlasil. Ale to se týkalo zejména Suchomelových recenzí, jichž jsem si začal cíleně všímat, zvláště Žertu, Sekyry a Spalovače mrtvol. Přiznávám se tímto $\mathrm{k}$ další nedůstojnosti: Většinu toho, čeho jsem se kdy v recenzní činnosti dopustil, mají na svědomí právě Suchomelovy semináře. Ostatně, když jsme se v druhé polovině 80 . let znovu setkali, přivítal mne svým typicky skeptickým tónem: „Aha, tak to jste vy!“

Pramálo toho vím o osudech Milana Suchomela v časech normalizace - tou dobou jsem se potloukal v kantorské roli po středních školách, později v redakční roli rozhlasáka docela vzdálen osudů pracoviště, kdež Milan Suchomel byl a nebyl, ale spíše byl, jak dosvědčují mnozí „dálkaři“ a postgradualisté z těch časů. Byl to možná právě on, kdo přilákal k pořádnému studiu i absolventy Rzounkovy pražské bohemistiky. Ale ze svých stanovisek neuhnul ani o píd’ a „vznešené umění dělat si nepřátele“ mu bylo vskutku vlastní.

$\mathrm{Na}$ konci osmdesátých let jsem po kratičké tři roky poznával Milana Suchomela také jako kolegu a $\mathrm{v}$ tom směru i přebohatou studnici informací o dílech a autorech, o nichž ještě stále nebylo radno zrovna nahlas vědět. $\mathrm{Ne}$, že by býval $\mathrm{v}$ tom směru zrovna řečný, ale na věcnou otázku dával věcnou odpověd a dovedl naznačit, kterým směrem případně pátrat po dalších informacích. S výjimkou 
výuky se na katedře moc nezdržoval: „Odcházím si číst,“ říkával, opouštěje pracovnu. Případně: „Odcházím psát.“ Někdy dokonce řekl o čem, a na případný doplňující dotaz, co si o předmětu svého zájmu myslí, odpovídal s nadhledem: „To já nevím, co mi z toho vyjde.“ Pokud mohu soudit, měl zdravé opovržení vůči zbytečným formalitám: $V$ tom směru občas s gustem citovával rozkošnou historku $\mathrm{z}$ fakultního folkloru. Její účinkující měli jistě velmi konkrétní jména, která mi zmizela v čase, ale příběh byl následující: „Pane profesore,“ oslovila v něm sekretářka vedoucího katedry, „máme tu ten nevyřízený přípis z děkanátu - a je po termínu!“

Pan profesor zachoval neprůstřelný klid: „A už nás upomínali?“

Podobné funkční stanovisko zaujímal Milan Suchomel i v osobním životě. Na konci 80. let bylo možno přejít bez nebezpečí po přechodu křižovatky od dnešního Ústavního soudu k tzv. Bílému domu - a to i na červenou. Milan Suchomel tak činíval docela pravidelně. Občas jsem se s ním těch dobrodružství účastnil při návratech z menzy. Zajímalo mne, jaké stanovisko by asi zaujal v případné konfrontaci s př́slušníky Veřejné bezpečnosti. Odpověd’ měl pohotově: „Když nic nejede, je čekání na zelenou pouhá formalita. Zákon má sloužit člověku, nikoli naopak." Jako racionální vysvětlení zločinného jednání to bylo skvělé; kdoví, jak by tenkrát obstálo v případné praxi.

Absolvoval jsem spolu se zástupy studentů také několik vlastivědných exkurzí katedry pod vedením toho znamenitého muže. Jako vedoucí se dostavoval vždy poslední, věren heslu, že poslední nikdy nečeká. Vzpomínám při té přiležitosti na tah kraji Máchovými od Litoměřic přes Kokořín až po zdolání ponurého Bezdězu. Všechny ty zastávky a výstupy doprovodil Milan Suchomel na místě vždy spatra přednesenými máchovskými přednáškami, jimiž beznadějně znehodnotil následující úsilí místních průvodců, zážitek, obávám se, už neopakovatelný. A dodnes jsem mu vděčen za objev barokního Manětína, o němž jsem neměl ani potuchy.

Poslední vzpomínka se vztahuje $\mathrm{k}$ obhajobám diplomových prací v letním semestru roku 90. Jedna ze Suchomelových diplomantek tenkrát porovnávala snad inscenace Olbrachtova Nikoly Šuhaje loupežníka v Divadle Husa na provázku a v Mahenově činohře. Externí oponent, skutečný autor slavné provázkovské dramatizace Balady pro banditu, zvučným basem předčítal nesmiřitelně kritický posudek, postavený na zásadním normativním argumentu, že vzhledem k autorčině nemožnosti osobně obě inscenace zhlédnout, je posuzovaná diplomová práce toliko odvozená $\mathrm{z}$ archivních materiálů - a jako taková bezcenná. Vypadalo to zle. 
Jenže ještě než se mohla otřesená diplomantka začít sama hájit, ozval se vedoucí její práce Milan Suchomel. Během pěti minut s neúprosnou logikou rozstřílel oponentovy názory $\mathrm{v}$ hromadu trosek - bylo to stejně drtivé, jako předcházející oponentův útok. Diplomantka pak už nad kouřícím bojištěm víceméně neměla co dodat. Toho bojovného ducha Milana Suchomela jsem se později pokoušel využít v rozhlase - nadšenou ochotou zrovna nepřekypoval, ale účastnil se několika debat na aktuální kulturní témata a své si vždy svým typicky ironickým způsobem řekl. Potíž byla jinde - v tom, že nebyl připraven sestoupit $\mathrm{z}$ akademické úrovně vyjadřování a argumentace, na niž, jak se záhy ukázalo, nedosahovali posluchači. $\mathrm{Na}$ tom postupně naše spolupráce uvadala, až k mé lítosti, ale bez zlé krve, pokojně zesnula. Pak už jsme se potkávali občas jen ve foyerech brněnských divadel na premiérách a při smutných přiležitostech posledních rozloučení s fakultními velikány. Ostatně i setkání, jímž jsem začal, mělo podobný ráz - byla to vzpomínková akce JAMU na Antonína Přidala.

Kromě vzpomínek chovám v knihovně dvě knihy Milana Suchomela: Literaturu z času krize, k níž se s potěšením vracím, když si potřebuji obnovit vývojové kontexty a souvislosti vývoje české prózy z let 1958-1967, a pak dvojknihu, tvořenou souborem třicítky Mahenových vskutku rozmarných próz Měsíc, doplněnou Suchomelovou studií Jiné oči Jiřího Mahena. V ní je kapitola, kterou mám před sebou jako věčný intelektuální úkol. Jmenuje se Systém, ale bláznivý. Je úžasná - ale vůbec jí nerozumím. Ve volných chvílích to zkouším znovu a znovu - ale nakonec se vždy ztratím. Svědčí to o nedůstojné ztrátě mé intelektuální schopnosti, ale věřím - nic než ta naděje mi ani nezbývá -, že jednou se mi konečně rozjasní.

Děkuji za vše, pane profesore, bylo a je to, jak vidíte, nezapomenutelné, byt poněkud nedůstojné. Naštěstí vás zřetelně slyším, jak říkáte: „Mohlo to být tak, ale docela určitě je to jinak."

Docela určitě. 